\title{
MENINGKATKAN HASIL BELAJAR SISWA MELALUI PENGGUNAAN ALAT PERAGA PADA SISWA KELAS III SDN 1 LELEWAWO
}

\author{
Ikhsan $^{1)}$, Yoo Eka Yana Kansil ${ }^{2)}$ \\ 1) SDN 1 Lelewawo, Kolaka Utara, Indonesia \\ ${ }^{2)}$ Jurusan PGSD, Universitas Halu Oleo, Kendari, Indonesia \\ email: $\underline{\text { Ikhsanlelewawo1975@gmail.com }}$
}

\begin{abstract}
Abstrak: Tujuan penelitian adalah untuk meningkatkan hasil belajar siswa pada materi penjumlahan dan pengurangan bilangan di kelas III SD Negeri 1 Lelewawo Kabupaten Kolaka Utara melalui model pembelajaran penggunaan alat peraga. Subyek penelitian ini adalah siswa kelas III yang terdaftar pada semester ganjil tahun ajaran 2016/2017 yang berjumlah 15 orang yang terdiri dari 6 orang laki-laki dan 9 orang perempuan. Penelitian ini terdiri dari dua siklus. Pendekatan yang digunakan terdiri atas empat tahap yaitu (1) perencanaan, (2) implementasi tindakan, (3) observasi dan interpretasi, dan (4) analisis dan refleksi. Hasil penelitian menunjukkan peningkatan melalui penggunaan alat peraga berupa kartu nilai. Hasil evaluasi siswa siklus I dengan nilai 53,33\% kemudian meningkat pada siklus II menjadi $86,67 \%$. Rata-rata nilai hasil belajar siswa pada siklus I sebesar 64 sedangkan rata-rata nilai evaluasi siklus II meningkat menjadi 76,38\%. Persentase aktivitas guru pada pertemuan pertama siklus I sebesar $72,22 \%$ dan pada pertemuan kedua meningkat menjadi $76,38 \%$ sedangkan pada siklus II pertemuan pertama sebesar $84,72 \%$ dan pertemuan kedua meningkat menjadi 97,22\%. Persentase aktivitas siswa pada siklus I pertemuan pertama sebesar $51,56 \%$ dan pada pertemuan kedua meningkat menjadi $64,06 \%$ sedangkan pada siklus II persentase aktivitas siswa pertemuan pertama sebesar $78,12 \%$ dan pertemuan kedua meningkat menjadi 90,62\%.
\end{abstract}

Kata Kunci: Media pembelajaran; alat peraga; hasil belajar siswa

\section{IMPROVING THE STUDENT'S LEARNING OUTCOMES THROUGH THE USE OF PROBLEMS IN CLASS III STUDENTS OF SD 1 LELEWAWO}

\begin{abstract}
The aim of the study was to improve student learning outcomes in the material of addition and subtraction of numbers in class III SD Negeri 1 Lelewawo, Kolaka Utara Regency through a learning model using teaching aids. The subjects of this study were 15 grade students registered in the odd semester of the 2016/2017 academic year, consisting of 6 boys and 9 girls. This study consisted of two cycles. The approach used consists of four stages, namely (1) planning, (2) action implementation, (3) observation and interpretation, and (4) analysis and reflection. The results showed an increase through the use of props in the form of scorecards. The results of the evaluation of students in cycle I with a value of $53.33 \%$ then increased in cycle II to be $86.67 \%$. The average value of student learning outcomes in cycle I was 64, while the average value of the evaluation cycle II increased to $76.38 \%$. The percentage of teacher activity at the first meeting of the first cycle was $72.22 \%$ and at the second meeting it increased to $76.38 \%$, while in the second cycle the first meeting was $84.72 \%$ and the second meeting increased to $97.22 \%$. The percentage of student activity in the first cycle of the first meeting was $51.56 \%$ and at the second meeting it increased to $64.06 \%$ while in the second cycle the percentage of student activity in the first meeting was $78.12 \%$ and the second meeting increased to $90.62 \%$.
\end{abstract}

Keywords: learning media; props; student learning outcomes 


\section{Pendahuluan}

Pembelajaran matematika sangat penting karena matematika merupakan ilmu universal yang mendasari perkembangan teknologi modern. Mempunyai peran dalam berbagai disiplin ilmu dan memajukan daya pikir manusia. Mata pelajaran matematika perlu diberikan kepada semua peserta didik mulai dari sekolah dasar dengan tujuan membekali peserta didik untuk memiliki kemampuan memperoleh, mengelola dan memanfaatkan informasi untuk mempertahankan hidup pada keadaan yang selalu berubah.

Berdasarkan hasil ulangan harian tahun ajaran 2015/2016 di kelas III SD Negeri 1 Lelewawo sebelum dilakukannya penelitian, nilai mata pelajaran matematika khususnya penjumlahan dan pengurangan bilangan masih tergolong rendah dan belum mencapai Kriteria Ketuntasan Minimal (KKM) yang ditetapkan oleh sekolah yakni 70. Data awal peneliti yang diperoleh dari guru kelas III bahwa dari 18 orang siswa yang tuntas hanya 12 orang $(66,66 \%)$ sedangkan 6 orang belum tuntas $(33,34 \%)$.

Sebelum penelitian dilakukan, guru mata pelajaran matematika di kelas III SD Negeri 1 Lelewawo, belum memanfaatkan alat peraga. Guru baru sebatas memanfaatkan metode ceramah serta penugasan (PR) kepada siswa. Secara operasional, guru menjelaskan materi kepada siswa kemudian memberikan contoh-contoh di papan tulis. Setelah selesai menerangkan materi, guru menyuruh siswa untuk mengerjakan soal yang terdapat dalam buku paket maupun buku LKS secara mandiri. Siswa kemudian disuruh maju ke depan kelas satu per satu untuk memberikan jawaban setiap soal yang dkerjakan.

Salah satu penyebab rendahnya pemahaman siswa terhadap materi matematika khususnya materi pecahan dan urutannya adalah kurangnya penguasaan konsep matematika dari siswa, karena untuk memahami konsep matematika yang sifatnya abstrak dibutuhkan aktivitas dan kreativitas yang tinggi dalam melakukan manipulasi objek matematika. Masalah lain yang menjadi penyebab rendahnya pemahaman siswa terhadap matematika khususnya materi pokok pecahan dan urutannya adalah metode mengajar guru serta model pembelajaran yang diterapkan oleh guru masih menggunakan metode ceramah sehingga siswa pasif dan terkesan hanya mendengarkan apa yang disampaikan oleh guru.

Media pembelajaran adalah suatu atau seperangkat alat yang merupakan saluran atau jembatan yang berfungsi untuk menyampaikan suatu pesan atau informasi dari sumber pesan ke penerima pesan. Penggunaan media pengajaran dapat membantu siswa untuk belajar sehingga hasil yang diharapkan dapat tercapai secara efektif dan optimal. Media pembelajaran memiliki beberapa manfaat, diantaranya yaitu pengajaran akan lebih menarik perhatian siswa sehingga dapat menimbulkan motivasi belajar siswa. Selain itu, bahan pelajaran akan lebih baik, menarik dan jelas maknanya sehingga dapat lebih dipahami para siswa dan meningkatkan penguasaan siswa terhadap tujuan pengajaran (Noor, 2010). Dalam proses belajar mengajar alat peraga mempunyai kedudukan yang sama pentingnya dengan komponen-komponen lainnya, karena pada dasarnya media berperan untuk meningkatkan kualitas siswa. Menurut Hamalik (2003) bahwa alat, metode, dan teknik dapat mengefektifkan komunikasi dan interaksi antara guru dan siswa dalam proses belajar mengajar. Dari pernyataan tersebut media dapat berbentuk alat, metode ataupun teknik mengajar yang dapat membawa suatu pesan pembelajaran.

Salah satu cara untuk mengatasi hal tersebut adalah pelaksanaan kegiatan tindak lanjut berupa pengajaran dengan menggunakan alat peraga. Alat peraga yang dipandang mampu mengatasi masalah tersebut adalah kotak bilangan dan kartu bilangan. Hal tersebut dimaksudkan agar siswa dapat mudah memahami dan menerima materi yang disampaikan guru yang secara tidak langsung memberi penekanan agar siswa memperhatikan penjelasan guru dan pada akhirnya siswa akan lebih memahami konsep dasar matematika yang dipelajarinya. Dengan demikian adanya pemahaman konsep tersebut maka akan dapat 
mengatasi rendahnya hasil belajar siswa. Mulyana dan Nana dalam Patimasang (2014) belajar merupakan perubahan perilaku sebagai fungsi pengalaman, yang mencakup perubahanperubahan afektif, psikomotorik, dan kognitif, yang tidak dihasilkan oleh sebab-sebab lain. Hasil belajar merupakan hasil keberhasilan dari interaksi belajar mengajar yang mencakup bidang kognitif, afektif, dan psikomotorik yang ditunjukkan dengan perubahan tingkah laku yang khas (Ulfah, 2016).

Alat peraga diharapkan dapat menjadi media dalam menyampaikan informasi pengajaran dan diharapkan juga dapat memberi motivasi belajar siswa. Alat peraga ini digunakan oleh guru untuk mempermudah tugasnya dalam mengajar. Alat peraga yang digunakan dapat dibuat oleh guru sendiri maupun siswa-siswa dalam kelompok maupun individual dan di dalam pembuatan maupun penggunaannya harus sesuai dengan materi yang diajarkan sehingga kegiatan belajar mengajarnya dapat efektif dan mencapai sasaran. Senada dengan Murdiyanto \& Yudi (2014) penggunaaan media maupun alat peraga secara kreatif akan memungkinkan siswa untuk belajar lebih baik dan dapat meningkatkan performan mereka sesuai dengan tujuan yang ingin dicapai.

Dahniar, dkk (2013) mengemukakan bahwa salah satu contoh pembelajaran yan dapat digunakan untuk siswa tingkat sekolah dasar khususnya kelas pemula yaitu kelas 1 melalui media berupa alat peraga dalam menyelesaikan soal cerita pada operasi penjumlahan dan pengurangan. Selain itu Sugiarto dalam Fujiati \& Mastur dalam Setyowati, dkk (2016) juga mengungkapkan bahwa dalam proses pembelajaran matematika sebaiknya siswa diberi kesempatan memanipulasi benda-benda konkret atau alat peraga yang dirancang secara khusus dan dapat diotak-atik oleh siswa dalam memahami suatu konsep matematika.

Pembelajaran matematika yang terjadi selama ini adalah pembelajaran yang hanya menekan pada perolehan hasil dan mengabaikan pada proses. Sehingga siswa mengalami kesulitan dalam mengerjakan dalam bentuk soal yang lain. Akibat dari pembelajaran yang hanya menekankan hasil adalah hasil yang dicapai tidak tahan lama atau anak akan mudah lupa pada materi pembelajaran yang dilaksanakan oleh guru. Diperlukan strategi belajar baru yang memberdayakan dan mendorong siswa mengkonstruksikan pengetahuan di benak mereka sendiri Hasrikah (2016). Menurut Fathani dan Abdul Hakim dalam Suwardi, dkk (2014) memahami matematika sebagai kontruktivisme sosial dengan penekanannya pada knowing how, yaitu pelajar dipandang sebagai makhluk yang aktif dalam mengonstruksi ilmu pengetahuan dengan cara berinteraksi dengan lingkungannya. Rahmanelli dalam Ismawati (2016), apabila anak terlibat dan mengalami sendiri serta ikut serta dalam proses pembelajaran maka hasil belajar siswa akan lebih baik juga pelajaran akan lebih lama diserap dalam ingatan siswa.

Berdasarkan hal tersebut di atas, penulis tertarik untuk melakukan penelitian dengan judul "Meningkatkan Hasil Belajar Siswa pada Materi Penjumlahan dan Pengurangan Bilangan Melalui Penggunaan Alat Peraga pada Siswa Kelas III SD Negeri 1 Lelewawo"

Masalah dalam penelitian ini adalah: apakah hasil belajar siswa pada materi penjumlahan dan pengurangan bilangan di kelas III SD Negeri 1 Lelewawo dapat ditingkatkan melalui penggunaan model pembelajaran alat peraga? Tujuan penelitian ini adalah untuk mengetahui efektivitas penggunaan alat peraga dalam pembelajaran matematika untuk materi penjumlahan dan pengurangan bilangan sehingga dapat meningkatkan hasil belajar siswa pada kelas III di SD Negeri 1 Lelewawo. Penelitian ini diharapkan dapat memberikan manfaat bagi guru, siswa, sekolah dan penelitian lainnya.

\section{Metode}


Jenis penelitian adalah penelitian tindakan kelas (PTK. Penelitian ini dilaksanakan pada kelas III SD Negeri 1 Lelewawo pada semester ganjil tahun ajaran 2016/2017 dengan subyek dalam penelitian ini adalah siswa kelas III SD Negeri 1 Lelewawo Kabupaten Kolaka Utara yang terdaftar pada semester ganjil tahun ajaran 2016/2017 berjumlah 15 orang. Penelitian tindakan kelas ini dilaksanakan dalam dua siklus yang terdiri dari empat tahapan yaitu perencanaan, pelaksanaan tindakan, observasi dan evaluasi serta refleksi Jenis data dalam penelitian ini adalah data kualitatif dan kuantitatif. Data kualitatif berupa kegiatan proses pembelajaran aktivitas belajar siswa dan aktivitas guru. Data kuantitatif berupa nilai hasil belajar siswa. Sumber data dalam penelitian ini adalah guru dan siswa Kelas V SD Negeri 1 Lelewawo Kabupaten Kolaka Utara.

Data kualitatif akan dianalisis secara deskriptif kualitatif berdasarkan observasi, sedangkan data kuantitatif dianalisis secara kuantitatif menggunakan rumus:

1. Menghitung tingkat pencapaian ketuntasan belajar secara individual

Secara individual \% TB $=\frac{\text { Nilai yang dicapai }}{\text { Skor maksimal }} \times 100 \%$

2. Menentukan persentase ketuntasan

$$
\% \mathrm{~TB}=\frac{\sum \mathrm{TB}}{\mathrm{N}} \times 100 \%
$$

Persentase rata-rata skor $=\frac{\text { Jumlah skor }}{\text { Butir yang diamati }} \times 100 \%$

(Usman, 1993)

Indikator keberhasilan dalam penelitian ini yaitu 1) Skenario pembelajaran dikatakan terlaksana dengan baik apabila $85 \%$ skenario pembelajaran terlaksana dengan sempurna. 2) Siswa-siswa yang menjadi subyek dalam penelitian ini dikatakan memahami konsep matematika yang diajarkan apabila minimal $80 \%$ siswa telah memperoleh nilai minimal 60 (ketentuan dari sekolah)

\section{Hasil}

\section{Hasil Belajar Siswa}

Siklus I, rata-rata hasil belajar siswa adalah 53,33 dan meningkat pada siklus II menjadi 86,67. Peningkatan skor perolehan hasil belajar siswa pada penelitian ini dapat dilihat pada Grafik 1 berikut:

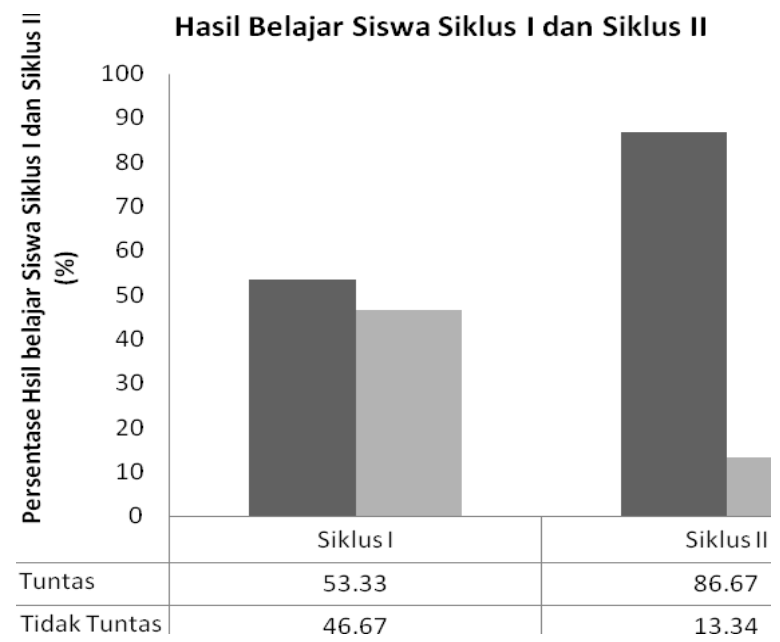

Grafik 1. Hasil Belajar Siswa Siklus I dan Siklus II

\section{Aktivitas Guru}


Pada siklus I, rata-rata persentase keberhasilan aktivitas mengajar guru adalah 74,3 $\%$ meningkat menjadi $90,97 \%$ pada siklus II. Peningkatan skor perolehan dan persentase keberhasilan aktivitas mengajar guru pada penelitian ini dapat dilihat pada Grafik 2. berikut:

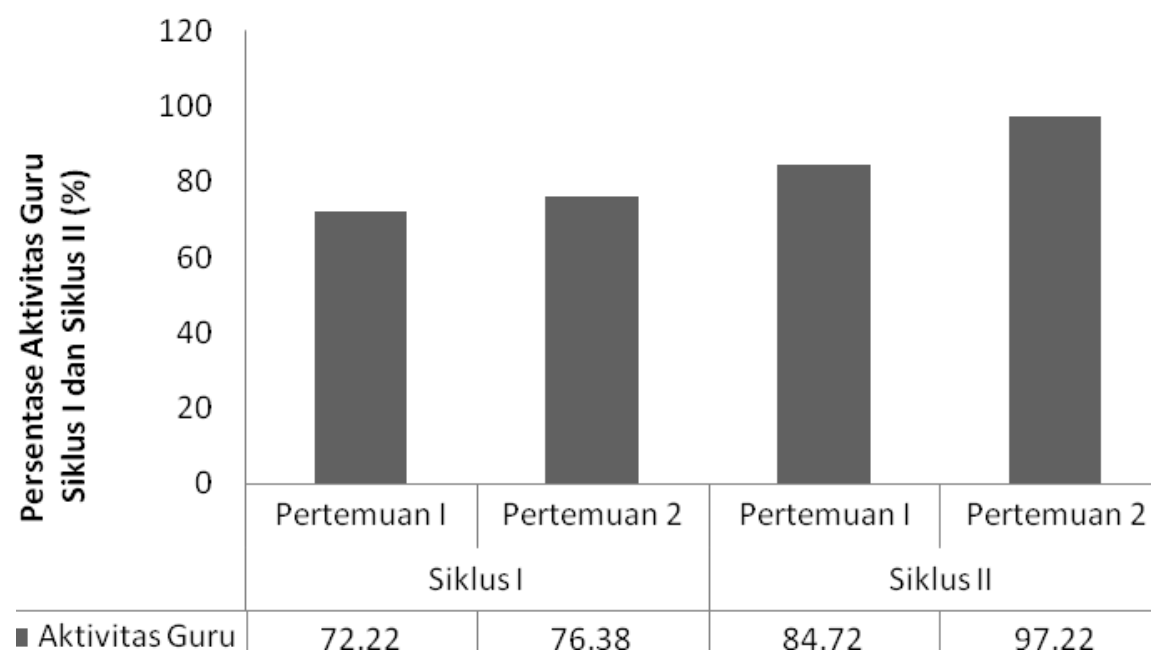

\section{Aktivitas Siswa}

Grafik 2. Aktvitas Guru Siklus I dan Siklus II.

Pada siklus I, rata-rata persentase keberhasilan aktivitas siswa adalah 57,81\% meningkat menjadi $84,37 \%$ pada siklus II. Peningkatan skor perolehan dan persentase keberhasilan aktivitas siswa pada penelitian ini dapat dilihat pada Grafik 3. berikut:

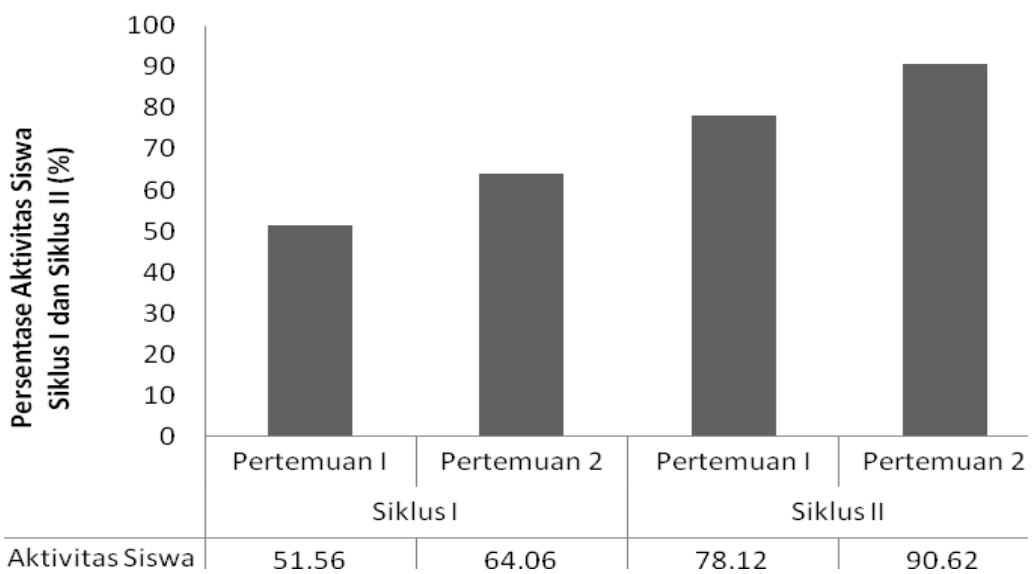

Grafik 3. Aktivitas Siswa Siklus I dan Siklus II

\section{Pembahasan}

Alat peraga merupakan alat bantu dalam pembelajaran dengan tujuan untuk memperjelas, memudahkan siswa memahami konsep karena pada dasarnya khususnya anak kelas III sekolah dasar, belum mampu memahami pelajaran dengan imajinasi sendiri sehingga dengan alat peraga proses pembelajaran menjadi nyata dan dapat menumbuhkan minat siswa dalam belajar.

Pelaksanaan penelitian terdiri dari dua siklus sesuai dengan prosedur yang ditetapkan. Observer mengobservasi guru dan siswa pada saat kegiatan pembelajaran. Berdasarkan hasil observasi pelaksanaan tindakan untuk siklus I, menunjukkan bahwa 
penerapan dengan menggunakan alat peraga belum sesuai dengan skenario pembelajaran yang telah disusun dan disepakati antara peneliti dan guru kelas III.

Pelaksanaan proses pembelajaran pada siklus I belum terlaksana secara maksimal. Hal tersebut dikarenakan siswa belum terbiasa dengan model pembelajaran yang diterapkan oleh guru sehingga mengakibatkan siswa kurang aktif dalam proses pembelajaran yang berdampak pada hasil belajar siswa. Sebelum dilaksanakan pembelajaran siklus I terlebih dahulu diadakan tes awal yang bertujuan untuk mengetahui perbandingan antara tingkat penguasaan siswa terhadap materi pelajaran yang diajarkan dengan penggunaan alat peraga. Hasil belajar siswa menunjukkan bahwa persentase ketuntasan hasil belajar siswa pada evaluasi siklus I sebesar 53,33\% dengan nilai rata-rata 64 kemudian meningkat pada hasil evaluasi siklus II yakni persentase ketuntasan mencapai $86,67 \%$ dengan nilai rata-rata 76,66. Menurut Hamalik dalam (Nupiksani, 2015) bahwa hasil belajar menunjukkan kepada prestasi belajar, sedangkan prestasi belajar itu merupakan indikator adanya derajat perubahan tingkah laku siswa.

Persentase aktivitas guru dan siswa mengalami peningkatan pada setiap proses pembelajaran mulai dari siklus I pertemuan pertama sampai pada siklus II pertemuan kedua. Persentase aktivitas guru pada pertemuan pertama siklus I, aktivitas guru hanya mencapai $72,22 \%$, pertemuan ke-2 meningkat menjadi $76,38 \%$. Siklus II pertemuan ke-1 meningkat menjadi 84,72\% selanjutnya pertemuan ke-2 meningkat menjadi 97,22\%.

Sedangkan persentase aktivitas siswa pada siklus I pertemuan ke-1, aktivitas siswa hanya mencapai 51,56\%, pertemuan ke-2 meningkat menjadi 64,06\%. Siklus II pertemuan ke1 meningkat menjadi $78,12 \%$ selanjutnya pertemuan ke-2 meningkat menjadi $90,62 \%$. Pengorganisasian proses belajar mengajar dikelas dengan strategi pembelajaran yang tepat adalah salah satu hal yang harus benar-benar dipahami oleh guru selaku pendidik untuk meningkatkan aktivitas sekaligus hasil belajar siswa (Untari, 2013).

Pelaksanaan pembelajaran pada Siklus II sudah terlaksana secara maksimal, hal tersebut karenakan siswa sudah terbiasa bahkan merasa senang dengan model pembelajaran yang diterapkan oleh guru sehingga mengakibatkan siswa aktif bahkan sangat antusias dalam proses pembelajaran yang berdampak pada hasil belajar siswa menjadi meningkat..

\section{Simpulan}

1. Persentase aktivitas siswa pada siklus I pertemuan pertama sebesar 51,56\%, meningkat menjadi $64,06 \%$ pada pertemuan kedua, selanjutnya meningkat menjadi $78,12 \%$ pada siklus II pertemuan pertama selanjutnya pada pertemuan kedua meningkat menjadi $90,62 \%$.

2. Persentase aktivitas guru pada pertemuan pertama siklus I hanya mencapai $72,22 \%$, pertemuan kedua meningkat menjadi $76,38 \%$ dan pada siklus II pertemuan pertama meningkat menjadi 84,72\% selanjutnya pertemuan kedua meningkat menjadi 97,22\%.

3. Persentase ketuntasan hasil belajar siswa pada evaluasi siklus I sebesar 53,33\% dengan nilai rata-rata 64 kemudian meningkat pada hasil evaluasi siklus II yakni mencapai $86,67 \%$ dengan nilai rata-rata 76,66 .

\section{Referensi}

Dahniar, I Nyoman Murdiana, \& Sukayasa. (2013). Penggunaan Alat Peraga Untuk Meningkatkan Hasil Belajar Siwa Kelas 1 SD Negeri 6 Tolitoli dalam Menyelesaikan Soal Cerita Tentang Penjumlahan Dan Pengurangan. Jurnal Kreatif Tadulako Online Vol. 4 No. 3. 165-177. https://media.neliti.com/media/publications/121502ID-penggunaan-alat-peraga-untuk-meningkatka.pdf 
Hamalik, O. (2003). Proses Belajar Mengajar. Jakarta: Bumi Aksara.

Harsikah. (2016). Penggunaan Alat Peraga Pada Pelajaran Matematika Untuk Meningkatkan Hasil Belajar Siswa Sekolah Dasar. Suara Guru: Jurnal Ilmu Pendidikan Sosial, sains, dan Humaniora Vol. 2 No. 3. 249-254. http://ejournal.uinsuska.ac.id/index.php/suaraguru/article/download/2663/1681

Ismawati. (2016). Penggunaan Alat Peraga Untuk Meningkatkan Hasil Belajar Siswa Kelas V SD Negeri 29 Pagaralam Tentang Sifat-Sifat Bangun Ruang. JPPM Vol. 9 No. 2. 230-234. DOI: http://dx.doi.org/10.30870/jppm.v9i2.1001

Murdiyanto, Tri \& Yudi Mahatma. (2014). Pengembangan Alat Peraga Matematika Untuk Meningkatkan Minat Dan Motivasi Belajar Matematika Siswa Sekolah Dasar. Jurnal $\begin{array}{lllll}\text { Sarwahita } & \text { Volume } & 11 & \text { No. } & 1 .\end{array}$ http://journal.unj.ac.id/unj/index.php/sarwahita/article/download/3318/2372/

Noor. M. (2010). Paikem Gembrot (Pembelajaran Aktif Kreatif Efektif Menyenangkan Gembira dan Berbobot). Jakarta: PT. Multi Kreasi Satu Delapan

Nupiksani, Sri. (2015). Meningkatkan Hasil Belajar IPS Melalui Penerapan Model Pembelajaran Group Investigation Pada Siswa Kelas VI SDN Rejoagung 01 Kecamatan Semboro Kabupaten Jember. Pancaran, Vol. 4, No. 4, hal 13-24. https://jurnal.unej.ac.id/index.php/pancaran/article/download/2174/1768/

Patimasang, (2014). Peningkatan Hasil belajar IPS dengan menggunakan Metode Kerja Kelompok pada Siswa Kelas IV SDN Silampayang. Jurnal Kreatif Tadulako Online Vol.2 No. 4. 132-150. https://media.neliti.com/media/publications/118659-IDpeningkatan-hasil-belajar-ips-dengan-men.pdf

Setyowati, N, Bambang, Eko Susilo, \& Masrukan. (2016). Penggunaan Alat Peraga untuk Meningkatkan Hasil Belajar dan Keaktifan Siswa pada Materi Peluang. Kreano 7 (1) (2016): 24-30. DOI: http://dx.doi.org/10.15294/kreano.v7i1.4831

Suwardi, Masni, Erika Firmiana, Rohayati. (2014). Pengaruh Penggunaan Alat Peraga terhadap Hasil Pembelajaran Matematika pada Anak Usia Dini. Jurnal Al-Azhar Indonesia Seri Humaniora, Vo. 2, No.4. 297-305. http://jurnal.uai.ac.id/index.php/SH/article/download/177/166

Ulfah, KR, Anang Santoso, \& Utaya, Sugeng. (2016). Hubungan Motivasi Dengan Hasil Belajar IPS. Jurnal Pendidikan: Teori, Penelitian, dan Pengembangan Volume: 1 Nomor: 8. 1607-1611. http://journal.um.ac.id/index.php/jptpp/article/view/6678/2885

Untari, Yusrina Anggraini. (2013). Peningkatan Hasil Belajar IPS Siswa Kelas V Melalui Metode Simulasi Improved Results of IPS Learning Student Class V through Simulation Method. Psikopedagogia Jumal Bimbingan dan Konseling. Vol. 2, No. 2. 78-84. http://journal.uad.ac.id/index.php/PSIKOPEDAGOGIA/article/view/2574/2792 